\title{
Restoring an Urban River-Polychlorinated Biphenyls and Other Contaminants in Bottom Sediment of the Lower Neponset River, Massachusetts
}

Robert F. Breault and Matthew G. Cooke

The U.S. Geological Survey studied sediment and water quality, with an emphasis on polychlorinated biphenyls (PCBs), in the bottom sediment and water of the Neponset River. The USGS completed this study in cooperation with the Riverways Program of the Massachusetts Executive Office of Environmental Affairs Department of Fish and Game, and the U.S. Environmental Protection Agency. The major findings of this study were:

- Human activities have adversely affected sediment quality in the Neponset River;

- With the exception of polyaromatic hydrocarbons and PCBs, contaminant concentrations are similar to those of other urban rivers;

- Sediment contaminant levels may adversely affect aquatic life and human health;

- PCBs continue to be released into the Neponset River;

- PCBs in the water may have toxic effects.

Urban River Restoration Requires Knowledge of the Quality of Impounded Sediment

In 1998, then Department of the Interior Secretary Bruce Babbitt reported that throughout its history America had constructed 75,000 dams. This number is, as Babbitt wrote, "the equivalent of one [dam being built] every day since Jefferson wrote the Declaration of Independence" (Babbitt, 1998). As these dams have aged, many have fallen into states of disrepair.

Dams commonly interfere with many natural processes in rivers. Blocking fish passage is perhaps the most widely recognized environmental effect of dams, but the reservoirs that dams create also inundate wetlands and terrestrial ecosystems; with dams, rivers become fragmented, and peak flows and other hydrologic characteristics are changed. Dams also change sediment regimes in a river by trapping most of the sediment moving downstream in impoundments behind the dams.

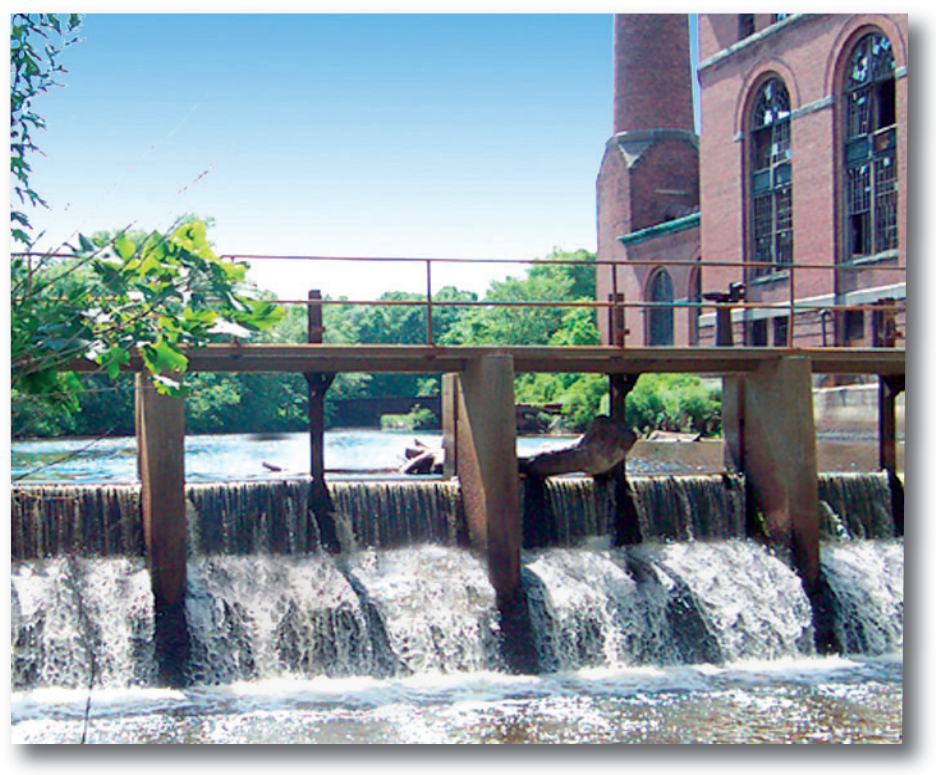

The Walter Baker impoundment, also known as the Lower Mills impoundment. Water from this impoundment once powered the Walter Baker Chocolate Factory, the first chocolate mill in America. The original dam was built in 1639 and is considered one of the first dams built in the New World.

Dams have impounded the Neponset River, a tributary to Boston Harbor, for the past 350 years (fig. 1). The river historically supported abundant populations of American shad and river herring. Presently (2003), the estuary supports an important rainbow smelt fishery.

Like most urban rivers in the Northeast, the Neponset River also has a long industrial history. Dam construction and settlement began as early as 1630 . By the mid 1700s, the Neponset River drained one of the most heavily industrialized basins in the Nation. Industrial activity continued on the Neponset River until 1965, when the last major industrial facility relocated from the lower section of the river. This industrial past, combined with the urbanization that continues in the drainage basin, has likely contaminated water, biota, and bottom sediment throughout the river.

\section{What is Riverways?}

The Riverways Program was established within the Department of Fish and Game (previously the Department of Fish, Wildlife, and Environmental Law Enforcement) in 1987 in recognition that river and stream corridors are a crucial component of the Commonwealth of Massachusetts's ecological infrastructure and that protection of these watershed resources could not be accomplished through land acquisition alone. Riverways encourages and supports local river-protection initiatives as a vital complement to state action. The mission of the program is to promote the restoration and protection of the ecological integrity of the Commonwealth's watersheds, rivers, streams, and adjacent lands (www.massriverways.org). 
Much effort by State, local, and Federal agencies has already been put forth towards restoring the Neponset River and surrounding areas, including the abatement of both industrial and sanitary discharges, greenway expansion, economic revitalization, and improving access to the river. Although there has been much improvement, work remains to be done. To that end, environmental managers and local advocates have evaluated river-restoration efforts, such as channel restoration for aquatic-habitat improvements, and fish-passage alternatives, including the installation of engineered fishways, dam breaching, and removal of the most downstream dams on the lower Neponset River - the Walter Baker Dam and the Tileston and Hollingsworth Dam. Fish passage at these dams would provide access to more than 17 miles of habitat to shad and herring and help increase recreational use on the lower Neponset River, that section of the river from Fowl Meadow to the Walter Baker Dam in Milton, MA.

Increased public dialogue about restoration of the Neponset River, combined with riverchannel alteration, the long history of industrialization and urbanization along the river, and some knowledge of the occurrence and geographic distribution of sediment contamination prompted this study of bottom-sediment quality and quantity. The U.S. Geological Survey (USGS) completed this study in cooperation with the Riverways Program of the Massachusetts Executive Office of Environmental Affairs (EOEA) Department of Fish and Game, and the U.S. Environmental Protection Agency (USEPA).

This fact sheet discusses the prevalence of trace elements and organic compounds in bottom sediment of the Neponset River. Because of the high concentrations of PCBs measured in the river and their high relative toxicities, this fact sheet focuses on the occurrence, source identification, and toxicity of PCBs in sediment and water of the Neponset River; other bottom-sediment contaminants are also briefly discussed.

The study described in this fact sheet consisted of the collection of 20 sediment-grab samples (from the top 2- 4 in. of sediment), 31 sediment-core samples (composited from 5 to 50 in., depending on the total depth of the sediment), and 12 measurements of PCB concentrations in the water column by using a passive water-sampling system (PISCES) (fig. 1). Sample-collection design and techniques, laboratory analysis, dataanalysis techniques, and quality-assurance and quality-control procedures are discussed in detail by Breault and others (2004).

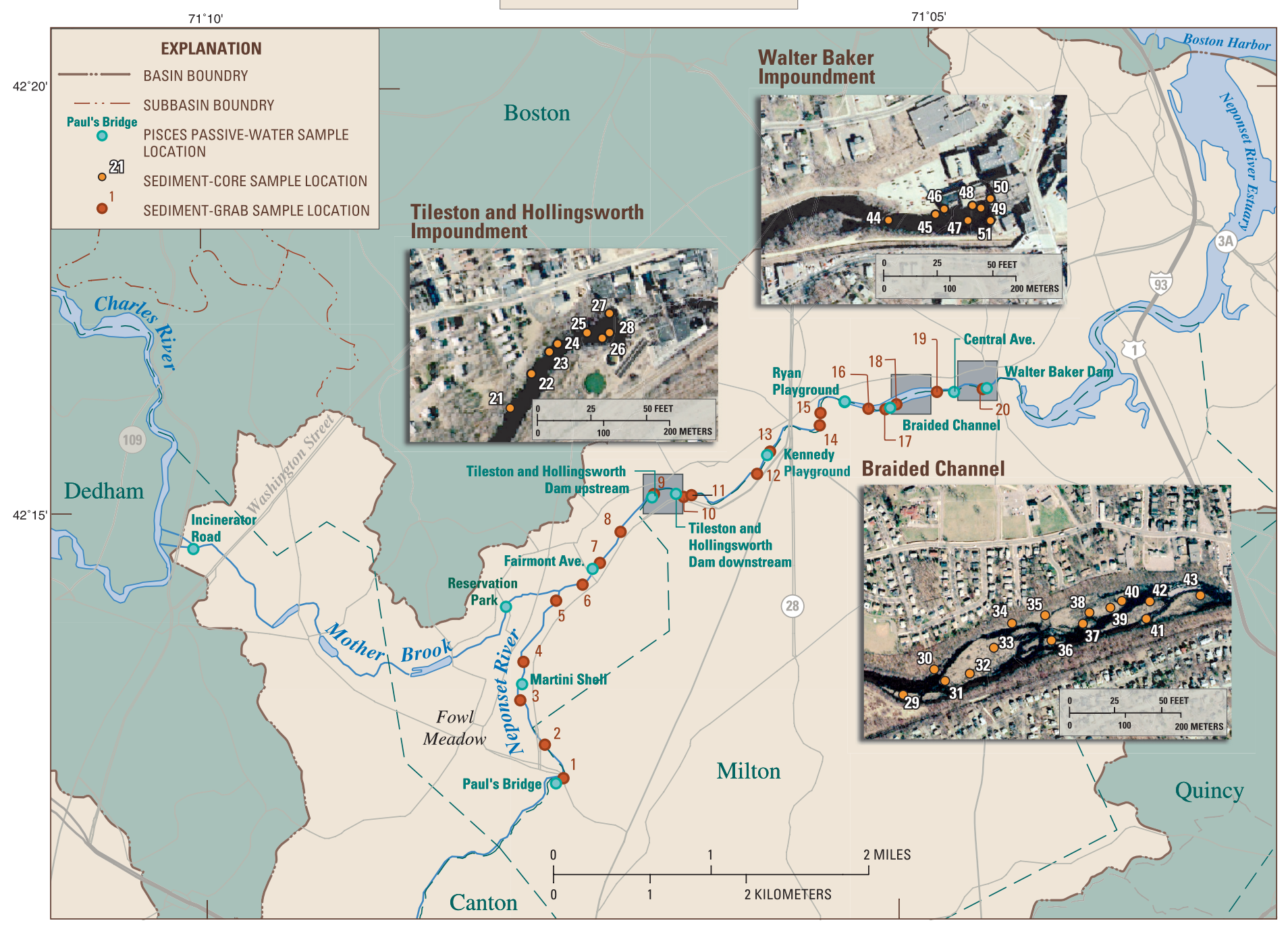

Figure 1. Sediment-grab (top 2-4 in. of sediment) and sediment-core (5-50 in., depending on the total depth of the sediment) sampling sites and location of passive-water-sampler (PISCES) deployment, in the Neponset River of Massachusetts. 

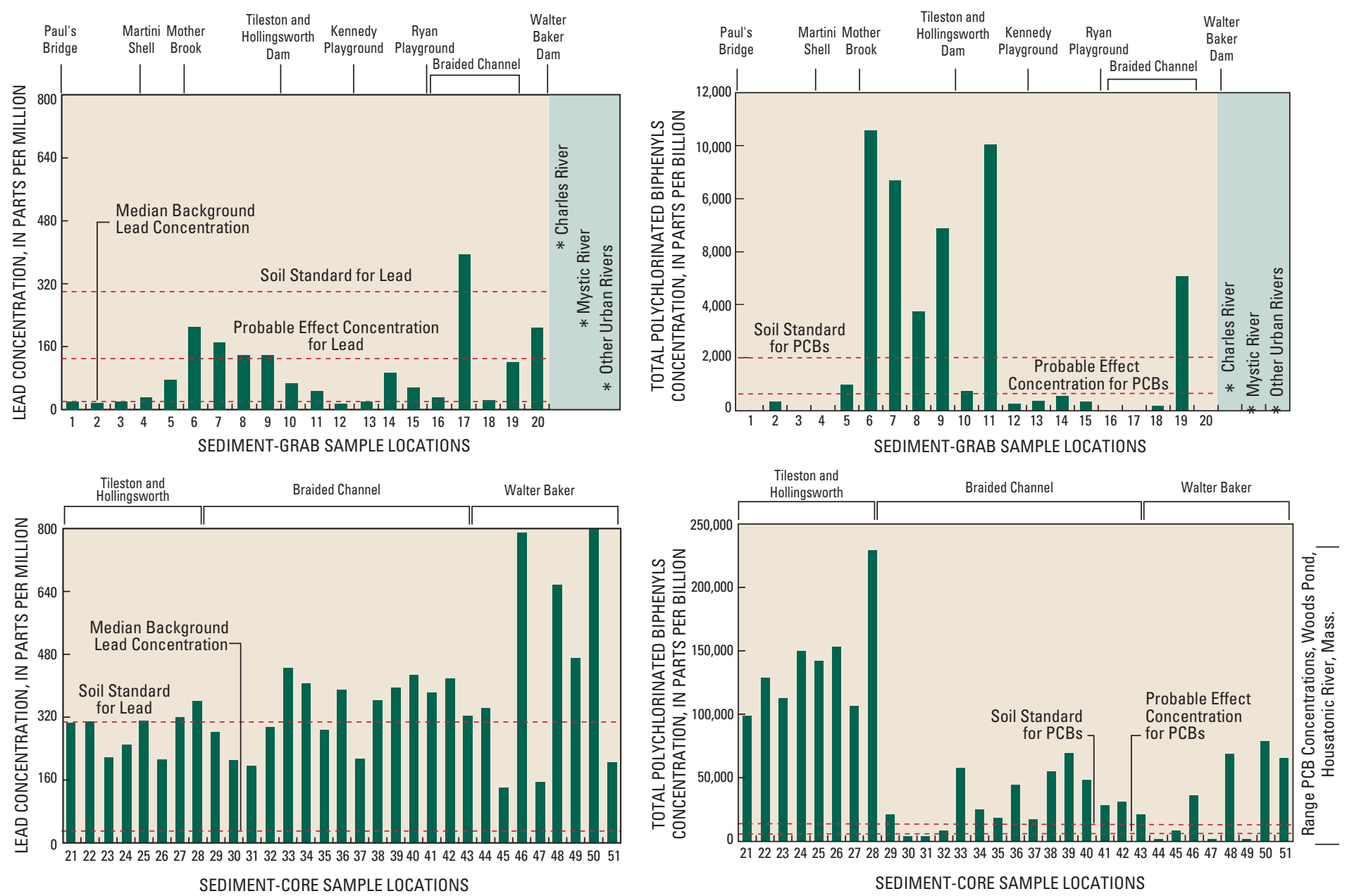

Figure 2. Lead concentrations measured in sediment samples collected from the Neponset River and median $\left({ }^{*}\right)$ lead concentrations measured in sediment-grab samples collected from the lower Charles and upper Mystic Rivers of Massachusetts and other urban rivers from across the United States. The direct-contact, exposure-based soil standard and probable effect and background concentrations for lead are also shown.

\section{Human Activities Have Adversely Affected Sediment Quality in the Neponset River}

Trace element concentrations measured in sediment samples from the lower Neponset River were compared to concentrations from selected New England streams, which for the purposes of this study represent "nonurban background" concentrations. This comparison shows that historical and recent human activities have affected many trace element concentrations, for example, concentrations of lead, a common contaminant resulting from human activities (fig. 2).

Figure 3. Total PCB concentrations measured in sediment samples collected from the Neponset River and median $\left({ }^{*}\right)$ total PCB concentrations measured in sediment-grab samples collected from the lower Charles and upper Mystic Rivers of Massachusetts and other urban rivers from across the United States. The range of PCB concentrations measured in a sediment-core samples collected from Woods Pond, the first impoundment downstream of a heavily PCB contaminated area on the Housatonic River, Massachusetts, probable effect concentration, and the directcontact, exposure-based soil standard for PCBs are also shown.

High concentrations of some trace elements in sediment, such as lead, are not unexpected in the Neponset River because of the historical and continued use of these trace elements in industry and the use of automobiles in the area around the Neponset River.

Unlike trace elements, organic compounds do not generally occur naturally in uncontaminated sediment; the detection of an organic contaminant is considered the result of human activities. Some polyaromatic hydrocarbons (products of

\section{Why Study Sediment Quality?}

The physical and chemical properties of most contaminants favor their close association with sediment. Contaminants of concern include elements and organic compounds, which can enter a river through waste disposal, urban runoff, sewers, atmospheric deposition, and inadvertent spills. As contaminated sediment travels downstream, it commonly accumulates in the slack water behind dams. Eventually, however, contaminants can reenter the water column through various processes; therefore, contaminated sediment in impoundments may be a perpetual source of contamination to the water in a river. 
What are PCBs?

PCBs, a group of manufactured organic compounds consisting of carbon, hydrogen, and chlorine, were first manufactured in 1881. Individual PCB compounds are called congeners. The 209 congeners differ from one another with respect to the number and position of chlorine and hydrogen atoms. Until the late 1970s, specific mixtures of congeners, called Aroclors, were commercially manufactured and sold. Originally, PCBs were used as flame retardants and as cooling and insulator fluids in electrical equipment, but the stable physical and chemical properties of PCBs also made them useful for home and office products, such as inks, dyes, and carbonless copy paper. These same properties make PCBs stable in the environment. This stability, and the health risks that PCBs pose to wildlife, plants, and humans, resulted in a ban of PCB usage by the USEPA in 1979.

incomplete combustion) were detected in most of the samples. Some PCBs (manufactured organic compounds) were also detected in most of the samples (fig. 3). Organochlorine pesticides, however, were not detected in the grab samples, but there were many detections of these pesticides in the core samples. Most notably, Chlordane, and the pesticides DDT, DDD, and DDE were detected in many core samples. The detection of these compounds in many core samples and not in any sediment-grab samples is expected. Because the use and disposal of these organic compounds were more prevalent in the past than in recent years, the products from past uses are buried in the sediment. The general use of DDT was banned in the United States in 1972. In 1988, the USEPA banned all uses of Chlordane.

\section{With the Exception of PAHs and PCBs, Contaminant Concentrations are Similar to Those of Other Urban Rivers}

Grab-sample data were compared with data from other urban rivers throughout the United States (Rice, 1999); the data were also compared with data from the lower Charles (Breault and others, 2000) and upper Mystic Rivers (Breault, unpublished data), two other urban tributaries to Boston Harbor. Sediment-core PCB data were also compared to data from the Housatonic River, a river in western Massachusetts with known PCB contamination (United States Environmental Protection Agency, 2003).

Concentrations of trace elements, like lead, in grab samples from the Neponset River are generally equal to or less than concentrations in sediment collected from other urbanized, free-flowing rivers (Rice, 1999; fig. 2). In contrast, organic compound concentrations, particularly PAHs and PCBs, are much higher in grab samples from the Neponset River. For example, median PCB concentrations measured in grab samples from the Neponset River are more than 125 times greater than those median concentrations in sediment samples from other rivers across the United States (Rice, 1999).

Generally, concentrations of many contaminants in sediment are lower in the Neponset River than they are in either the Charles or the Mystic Rivers. In contrast, concentrations of PCBs in sediment in the Neponset are similar to those in the Charles and greater than those in the Mystic River. Some parts of the Neponset River are highly contaminated with PCBs, particularly within current impoundments and former impounded areas (fig. 3).
To assess the contamination severity, it is useful to compare PCB concentrations measured in sediment cores collected from current impoundments and former impounded areas of the Neponset River to concentrations in sediment samples collected from the Housatonic River (fig. 3). Although concentrations are higher in the Housatonic River than those in the Neponset River, concentrations in sediments of the first impoundment (Woods Pond) downstream of the heavily contaminated area in the Housatonic River are comparable to the concentrations in the sediments of the Tileston and Hollingsworth impoundment in the Neponset River (U.S. Environmental Protection Agency, 2003).

\section{Sediment Contaminant Levels May Adversely Affect Human Health and Aquatic Life}

River-restoration efforts often focus on bringing people and river together. When a river is restored, access to it improves, recreational opportunities increase, and more people fish, swim, and boat in the river. As people interact with the river, they will likely come in contact with sediment.

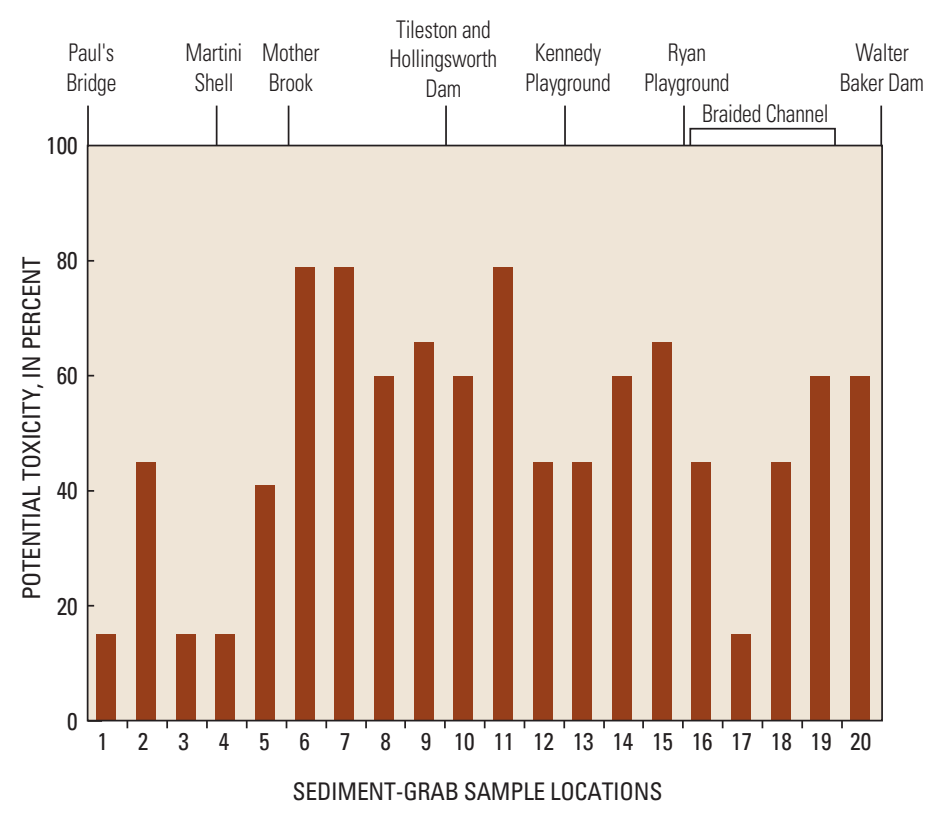

Figure 4. Estimated average potential toxicity for the top 2-4 in. of bottom sediment collected from the Neponset River. For example, a sediment sample with an estimated potential toxicity of 15 percent means that 15 out of 100 toxicity tests are likely to show some level of toxicity for the contaminant concentrations measured in that sediment sample. 


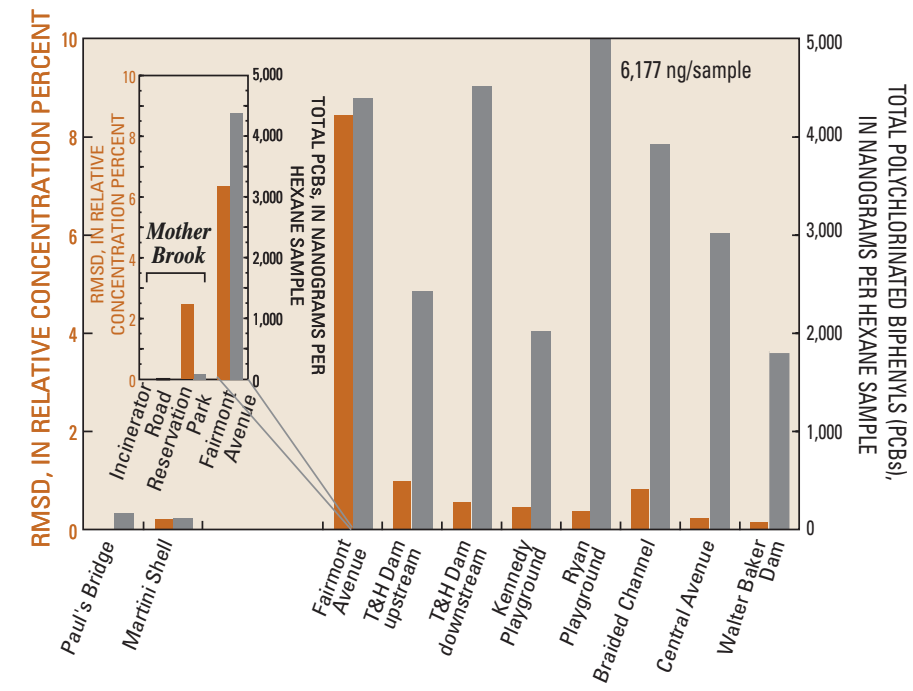

Figure 5. Mean PCB concentration measured in passive-water samplers (PISCES) and the degree of the change in PCB congener pattern (or fingerprint) along the Neponset River-as indicated by the statistic root mean square difference (RMSD). The most likely source of PCBs to the Neponset River is somewhere between the Martini Shell and Fairmont Avenue sampling locations or between Reservation Park and Fairmont Avenue.

Information about human health risks associated with contaminated sediment would allow water-resource managers to plan their river-restoration efforts. Potential human health effects can be indirectly assessed by comparing sedimentcontaminant concentrations with exposure-based guidelines. These guidelines, however, do not exist for aquatic sediment, but they do exist for contaminated upland soil (Massachusetts Department of Environmental Protection, 1996).

Soil standards exist for many of the constituents tested; but in the sediment samples, only a few of the constituents were detected at concentrations near or above the soil standard. More importantly, however, PCBs and some PAHs, when considered in relation to the direct-contact, exposure-based soil standards, may represent the greatest human health risk in the Neponset River (fig. 3).

By comparing contaminant concentrations to sedimentquality guidelines, known as probable effects concentrations, sediment quality is quantifiable in terms of potential adverse biological effects to benthic organisms, which live and feed in the river bottom and are an important food source for much of the other life in the river (Ingersoll and others, 2000). The average estimated toxicity potential to benthic organisms ranged from about 15 percent to 80 percent among the grab samples (fig. 4). For example, a single sediment sample with an estimated potential toxicity of 15 percent indicates that 15 out of 100 toxicity tests on that single sample likely will show toxicity. In this study, trace metals and PAHs accounted for some potential toxicity. More importantly, PCBs were most responsible for predicted toxicity (Ingersoll and others, 2000).

\section{PCBs Continue to be Released into the Neponset River}

PISCES samplers, deployed in the water column, absorb PCBs from the water across a semipermeable membrane into a sample of hexane, in which they dissolve and accumulate. Sample analysis shows a characteristic pattern of individual PCB compounds, known as congeners, which can be characteristic of a PCB source, in the same way that fingerprints are unique to an individual. The degree of difference between these patterns in samples collected from adjacent sampling locations can be analyzed with a statistic known as the root mean square difference (RMSD). Statistically, different RMSD values indicate a measurable difference in congener pattern between sampling locations and thus potentially different PCB sources (Breault and others, 2004).

The most likely source of dissolved PCBs to the Neponset River, as indicated from PISCES data, is bottom sediment downstream from Fairmont Avenue. This PCB contaminated sediment was likely transported from a historic source and deposited in this part of the river. The point of maximum change in PCB congener pattern measured in bottom sediment coincides with that of the PISCES samples (fig. 5). These data are consistent with a historic source located just upstream from Fairmont Avenue. Alternatively, the change in

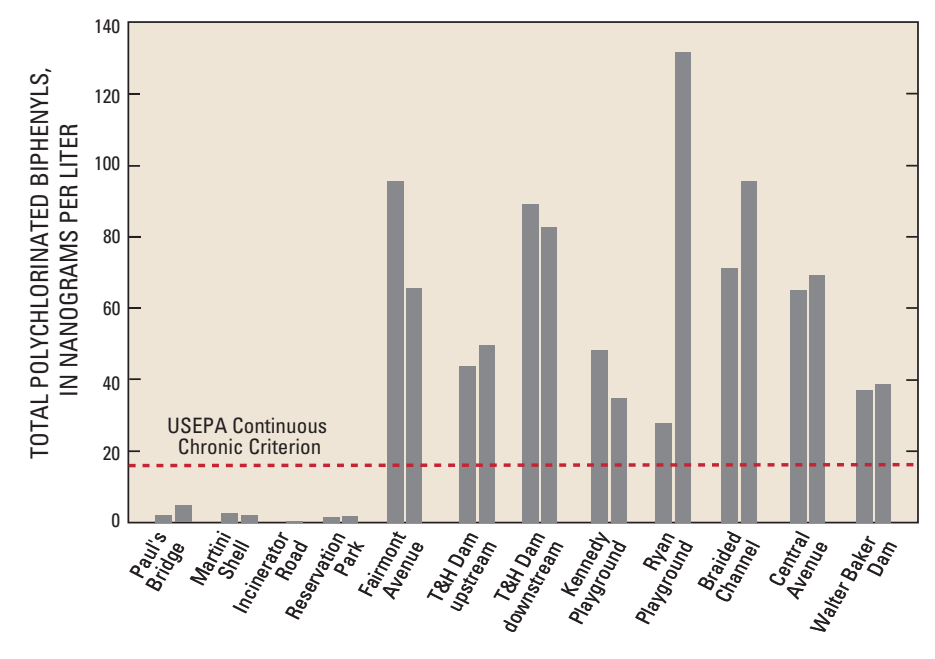

Figure 6. Concentrations of PCBs dissolved in the water estimated from duplicate PISCES samplers at each location. Water concentrations increase sharply downstream of the Fairmont Avenue PISCES sampling location and generally decrease downstream of that location. Estimated concentrations of PCBs dissolved in the water downstream (left to right) of the Fairmont Avenue PISCES sampling location exceed the U.S. Environmental Protections Agency's (USEPA) freshwater concentration limit (continuous chronic criterion) for PCBs dissolved in water.

\section{How Do PCBs Affect Aquatic Life?}

As predatory aquatic organisms eat other organisms such as smaller fish or organisms that feed and live on bottom sediments contaminated with PCBs, the predatory organism can become contaminated. Aquatic organisms may also become contaminated directly from the water column by absorbing dissolved PCBs through gill membranes or skin. 
congener pattern could be caused by anaerobic degredation of the historic PCB contamination in the depositional zone in that part of the river. In this case, the historic source would be located farther upstream (Breault and others, 2004).

\section{PCBs in the Water May Have Toxic Effects}

Because PCBs affect fish, wildlife, and human health, environmental management agencies, including the USEPA, set maximum acceptable values for PCBs in water. The current acceptable value for PCB concentrations in freshwater is 14.0 parts per trillion (ppt).

PISCES sample data indicate that PCB concentrations in Mother Brook (average estimated PCB concentration equal to $1.2 \mathrm{ppt}$ ) or in the Neponset River upstream of Fairmont Avenue (2.8 ppt) would not be expected to cause adverse biological effects. On the other hand, exposure to PCBs downstream of the Fairmont Avenue sampling location (66 ppt) may adversely affect aquatic organisms or wildlife (fig. 6).

Although PCB concentrations in aquatic organisms were not directly measured, they were estimated from the PISCES data (Breault and others, 2004). Average PCB concentrations in predatory-fish fillets (edible fish parts) were estimated to range from about 0.04 parts per million (ppm) to $0.3 \mathrm{ppm}$ upstream of the Fairmont Avenue sampling location and to be about $0.9 \mathrm{ppm}$ downstream of the sampling location. These concentrations are similar to those measured by the Massachusetts Department of Environmental Protection (MDEP) in 1994 (Massachusetts Department of Environmental Protection, 1994). On the basis of the MDEP findings, the Massachusetts Department of Public Health issued a fish-consumption advisory for brown bullhead collected from the Neponset River between the Hollingsworth and Vose Dam (Walpole, MA) and the Tileston and Hollingsworth Dam (Hyde Park, MA).
The organic compound dioxin is among the most toxic of substances found in the environment. Of the 209 PCB congeners, 13 are considered dioxin-like; that is, they cause toxic effects similar to those caused by dioxin. Because of this similarity, the toxicity of these congeners can be assessed in relation to the toxicity of dioxin. This assessment is referred to as toxic equivalency (TEQ).

Estimated PCB water-column concentrations in the Neponset River, when expressed in terms of TEQ, were generally near or slightly greater than the USEPA humanhealth standard for dioxin $(0.000005 \mathrm{ppt})$, except for the sample from the Incinerator Road location. The largest total TEQ was calculated for the samples collected just downstream of the Tileston and Hollingsworth Dam. At this sampling location, the TEQ was estimated to be about 10 times greater than the standard.

\section{Sediment-Quality Data Support Future River- Restoration Decisions}

The data presented here will help environmental managers evaluate the advantages and limitations of fish-passage alternatives and sediment-management options. Possible options include dredging and removal of contaminated sediment, channel restoration with stabilization of contaminated sediment, and breaching and removal of dams allowing for redistribution of contaminated sediment downstream. Knowledge of existing concentrations and distribution patterns of contaminants in the river will help guide the selection of the most cost-effective and environmentally beneficial riverrestoration strategies. Restoration of the lower Neponset River will preserve this valuable resource and ultimately contribute to the protection of the Neponset River Estuary and Boston Harbor.

\section{References Cited}

Babbitt, Bruce, 1998, A river runs against it-America's evolving view of dams, in Open Spaces Quarterly, v. 1, no. 4, accessed March 31, 2003, at http://www.open-spaces.com/article-vln4babbit.php, p. 5 .

Breault, R.F., Cooke, M., and Merrill, M., 2004, Sediment quality and polychlorinated biphenyls in the lower Neponset River, Massachusetts, and implications for urban river restoration: U.S. Geological Survey Scientific Investigations Report 2004-5109, 48 p.

Breault, R.F., Reisig, K.R., Barlow, L.K., and Weiskel P.K., 2000, Distribution and potential for adverse biological effects of inorganic elements and organic compounds in bottom sediment, Lower Charles River, Massachusetts: U.S. Geological Survey WaterResources Investigations Report 00-4180, 70 p.

Ingersoll, C.G., MacDonald, D.D., Wang, N., Crane, J.L., Field, L.J., Haverland, P.S., Kemble, N.E., Lindskoog, R.A., Severn, C., and Smorong D.E., 2000, Prediction of sediment toxicity using consensus-based freshwater sediment quality guidelines: Chicago, IL, U.S. Environmental Protection Agency, EPA 905/R-00/007, June 2000, 25 p.
Massachusetts Department of Environmental Protection, 1994, The Neponset River Watershed 1994 resource assessment report: Boston, MA, Massachusetts Executive Office of Environmental Affairs, variously paged.

Massachusetts Department of Environmental Protection, 1996, Massachusetts contingency plan: Boston, MA, Massachusetts Department of Environmental Protection, variously paged.

Oliver, B.G. and Niimi, J.A., 1985, Bioconcentration factors of some halogenated organics for rainbow trout-limitations in their use for prediction of environmental residues: Environmental

Science and Technology, v. 19, no. 9, p. 842-849.

Rice, K.C., 1999, Inorganic-element concentrations in streambed sediment across the conterminous United States: Environmental Science \& Technology, v. 33, no. 15, p. 2499-2504.

U.S. Environmental Protection Agency, 2003, GE/Housatonic River Site in New England, accessed February 3, 2004, at http://www.epa.gov/region1/ge/thesite/restofriver-maps.html, p. 1. 